\title{
LEGAL PROTECTION AGAINST DEPOSITORS' CUSTOMERS WITH MUDHARABAH CONTRACT ON ISLAMIC BANKS
}

\author{
Elvira Fitriyani Pakpahan \\ Universitas Prima Indonesia, Medan, Indonesia \\ elvirapakpahan@unprimdn.ac.id
}

\begin{abstract}
Deposit type most often used by Islamic Bank in collecting funds from the public is revshare system (mudharabah) where the customer is acting as an investor and profit from business carried on by the bank. But in practice mudharabah can also loss caused by managers (Banks) in running the business. The problem in this research is how the legal protection of depositors with mudharabah in Islamic banks. With normative juridical research method and approach to literature. Results of the study stated that the legal protection of depositors in Islamic banking are protected by rules that are already fairly well from the Financial Services Authority and the Institute of deposit insurance, even the rules better than protection applied to customers of conventional banks. LPS in Regulation 2 of 2010 Article 44 stated that the interest rate is considered reasonable set LPS does not apply in determining the status of the deposit guarantee to deposits based on Islamic principles because Islamic Bank using revshare principle in operation.
\end{abstract}

\section{A. INTRODUCTION}

Banking institution that serves as a collecting and distributing public funds (financial intermediary) have a strategic role to support the implementation of national development, namely in order to improve the distribution of development. ${ }^{1}$ In 1997, Southeast Asia experienced a financial crisis that could change Indonesia's economy collapsed. This has an impact to companies that exist in the country, especially in the banking sector at the time. Banking institutions is one of the backbone of the economy of a country because it serves as intermediary institutions increasingly affected. One of the problems that arise are many

1 Kuncoro, Mudrajad. Manajemen Perbankan: Teori dan Aplikasi.Yogyakarta: BPFE, 2002, p. 21 customers who have failed to pay, resulting in the bank suffered very big losses.

Islamic banks in this case PT. Bank Muamalat Indonesia proved to be a financial institution that can survive amid increasingly severe economic crisis. Islamic banking revenue sharing system applied in the bank relative maintain its performance and is not washed away by the level of deposit rates are soaring to lower operating expenses than conventional banks. In general the effectiveness of Islamic banking intermediation function is maintained as the growth of the funds raised and the financing is relatively high compared to the national banking system, as well as providing increased network access and address the needs of the broader community so that it 
can make the financial performance of Islamic banking better.2

As a financial institution Islamic Bank acts as intermediary institution in Bank Indonesia Regulation Number: 9/19/PBI/2007 regarding the implementation of Sharia in activities Deposits and Funds Distribution And Services Islamic Bank, in the activities of fund raising Islamic Bank using syariah contract-based principle among others Akad Wadi'ah and Mudharabah. In Act 21 of 2008 concerning Islamic Banking, explains the definition of savings as a deposit based on the principles wadi'ah or investment funds based on the Mudharabah contract or other agreement that does not conflict with Islamic principles that may only be withdrawn under certain terms and conditions are agreed, but can not be withdrawn by check, demand deposit, and/or other equivalent means of it3.

Deposits with Wadi'ah contract, an Islamic bank products where customers can deposit funds to the bank, and customers can withdraw funds when at any time. While deposits with Al-Mudharabahh contract, a product of Islamic banks in which the cooperation between the two parties; The first party as a financier and the second as a manager. The benefits will be divided according to the agreement. While the losses will be borne by the capital provider for damages not caused by the negligence of the manager. If the loss is due to negligence and fraud manager, then the losses will be borne by themanager. In practice using Mudharabah contract Bank received

2 Arifin, Zainul. Dasar-Dasar Manajemen Bank Syariah. Jakarta: Alvabet, 2005, p.102

3 Law of the Republic of Indonesia No.21 of 2008 concerning Sharia Banking funds from the Customer (shahib mall) in the form of third-party funds as a source of funds. These funds could take the form of savings or deposits Mudharabah with variable periods. Furthermore, the funds that have been collected are channeled back by the bank in the form of financing generates (earning assets). The advantage of this finance portfolio will be divided between the bank and the owners produce Third Party Funds.

The most important principle of Mudharabah is when profits are shared among Shahibulmal and mudharib, all the losses in the investment or business covered by the capital alone, unless the loss is caused by the inappropriate action or omission occurs mudharib. If there is no inappropriate action and negligence, Mudarib is not responsible for losses in the business.4 Based on data from the OJK (Financial Services Authority) Mudharabah savings is a form of savings that most large proportion compared with other savings products with a contract with a percentage of $67 \% .5$ Although persetase very high growth even Islamic Bank exceeds the growth of the national conventional banks with CAR, RoA, which is getting better and better able to suppress NPF of 2017 ago. ${ }^{6}$ It is not possible Islamic Bank's financial performance using the principles Revshare experiencing adversity in the years to come.

4 Zamir Iqbal Abbas Mirakhor, Pengantar Keuangan Islam Teori dan Praktek, Jakarta: Kencana Prenada Media Group, 2008, p.131

5 Islamic Banking Statistics November 2018

6 https://republika.co.id/berita/ekonomi/syariahekonomi/19/02/07/pmjysr370-pengamatperforma-perbankan-syariah-2018-semakinkuat 
Deposit type most often used by Islamic Bank in collecting funds from the public is revshare system (Mudharabah) where the customer is acting as an investor and profit from business carried on by the bank. But in practice Mudharabah can also occur losses caused manager (Bank) in business so that when it happens customers who act as investor (Shahibul mall) will bear own losses incurred during the loss is not an omission Bank (mudharib). In running his business. For this reason, it is necessary to discuss legal protection against depositors' customers with mudharabah in Islamic banks. The research method used is normative juridical approach to literature

\section{B. DISCUSSION}

Legal protection for depositors has been set up in various forms such legislation, the Law of the Republic of Indonesia Number 21 Of 2011 about the Financial Services Authority (State Gazette of the Republic of Indonesia Of 2011 Number 111, Supplement to the State Gazette of the Republic of Indonesia Number 5253). This law provides for the functions, duties and authority to regulate and supervise the activities in the financial services sector. Related setting legal protection for consumers and society contained in Chapter VI of Consumer Protection and Public Articles 28, 29, 30 and 31.

Under Article 29 of the above, one of the OJK authority in conducting consumer protection is to create a mechanism for consumer complaints in financial services institutions, it means that the OJK is also authorized to make a complaint mechanism depositors Microfinance Institutions as a financial services institution. It is also based on the transition part of the duties and authority of Bank Indonesia to the OJK in terms of supervising financial institutions described in Article 69 subjection (1), which explains that the task of Bank Indonesia in organizing and supervising the Bank were transferred to the OJK related to the task of managing and controlling of with microprudential ie about institutional, health, financial services institutions, aspects of the prudential and bank checks,

Regulation of the Financial Services Authority No. 1/POJK.07/2013 about Consumer Protection Financial Services Sector. These regulations established by the mandate of Article 31 of Act No. 21 Of 2011 on the Financial Services Authority, should be set OJK Regulation about Consumer Protection for Financial Services Sector.

Legal protection for customers have the right to conduct customer complaints, as well as the use of banking mediation forum to obtain the settlement of disputes in the field of banking in a simple, cheap, fast. If the rights and obligations of liquidated banks are in line with the Consumer Protection Act will be able to carry out banking activities within the bank. Among them are the right to safety, the right to choose a product, the right to obtain clear and accurate information and the right to be treated properly and honestly. And obligation is to follow the instructions of information and procedures that run the bank. ${ }^{7}$

Bank relationships with customers is generally a civil relationship. Such relations, in practice it does not always run smoothly, it could be disagreement or dispute arising between them. In the

7 David Y. Wonok, Perlindungan Hukum Atas HakHak Nasabah Sebagai Konsumen Pengguna Jasa Bank Terhadap Risiko Yang Timbul Dalam Penyimpangan Dana, Vol.I/No.2/AprilJune/2013 Special Edition. p.5 
event of a dispute concerning Islamic banking, the settlement of the dispute, in principle, carried out by the court within the Religious Courts (Article 55), but if the parties have another pledge, dispute settlement is done in accordance with the contents of the agreement. Thus in addition to the settlement of disputes Islamic banking can be done through the Religious Courts (according to Act No. 3 of 2006 on the Amendment of Act No. 7 of 1989 on the Religious Courts), can also choose the settlement of disputes through negotiation, mediation banking, Basyarnas, or general courts, However, ${ }^{8}$

\section{The Deposit Insurance Agency as a guarantor of deposits.}

The Deposit Insurance Agency (LPS) is a state institution with the legal status of an independent, transparent and accountable in carrying out its duties and is directly responsible to the President. Then, as stipulated in Article 62 of Act No. 24 of 2004 concerning the Deposit Insurance Corporation hereinafter referred to as the Act LPS, governance the Deposit Insurance Agency is One board system, namely the Board of Commissioners as the head of the Deposit Insurance Agency which is responsible for formulating and decide policy, and to supervise the execution of duties and authorities of the Deposit Insurance Agency. In Article 65 of Law LPS, the Board of Commissioners determined by the President and has the authority.

8 Arief R. Permana, S.H., M.H.1 dan Anton Purba, S.H., LL.M, Sekilas Ulasan Uu Perbankan Syariah, BULETIN Hukum Perbankan Dan Kebanksentralan 1. Volume 6, No. 2, August 2008
In performing their duties, as stipulated in Article 7 of Law LPS, the Board of Commissioners shall conduct regular meetings known as the Board of Commissioners to discuss the following matters:

a. Establish client insurance policy.

b. Establish policies Deposit Insurance Institution in supporting the stability of the banking system.

c. Evaluating the implementation of the guarantee of customer deposits and the implementation of the Deposit Insurance Agency's role in supporting the stability of the banking system.

d. Receiving and evaluating things that are reported to the Chief Executive; and / or

e. other matters relating to the Deposit Insurance Agency task.

The Deposit Insurance Agency is an independent institution, transparent, and accountable in carrying out its duties and authorities. The Deposit Insurance Agency has a very important function, namely as set out in Article 4 of the Law on the Deposit Insurance Agency., Namely:

1. Guaranteeing deposits of depositors.

2. Actively participate in maintaining the stability of the banking system in accordance with their authority.

In its function as a guarantor of deposits of depositors, the Deposit Insurance Agency is responsible for determining and formulating policies for the implementation of deposit insurance and to implement the deposit guarantee. and when the closure of failed banks, deposit insurance duty is applied to make payments on insurance claims bank 
customer deposits were withdrawn, and appointed a liquidation team to clean up the bank's assets and liabilities. ${ }^{9}$

The Deposit Insurance Agency to make payments to the insurance claims depositors of banks that license has been revoked far as they meet the requirements stipulated by the Law on Insurance Agency ${ }^{10}$

1. Recorded in the books of the bank.

2. The deposit interest rate does not exceed the interest rate guarantee.

3. Do not perform actions that harm the bank.

These three criteria are eligible to pay the aforesaid known as 3T. But for the interest rate on deposits do not exceed the interest rate guarantee does not apply to Islamic banks. LPS in Regulation 2 of 2010 Section 44 is stated that the interest rate is considered reasonable set LPS does not apply in determining the status of the deposit guarantee to deposits based on Islamic principles.

Payment of insurance claims can be made in cash or other equivalent payments and any payments made in the currency. Deposits in foreign currencies are paid based on the middle rate of Bank Indonesia. In case the depositor at the same time have obligations to the bank, the payment of insurance claims made after the obligations of

9 Indra atmaja Agung B.G.B , Lembaga Penjamin Simpanan: Manfaatnya Bagi Nasabah dan Bank, Jakarta : Magister Hukum Universitas Indonesia, 2001.

10 Mamuja, Juanda. Lembaga Penjamin Simpanan Dalam Rangka Perlindungan Hukum Bagi Nasabah Perbankan DiIndonesia. Lex Privatum, Vol.III/No. 1/Jan-Mar, 2015. the depositor to the bank prior calculation $^{11}$

Deposit Insurance Agency determines, claim payment paid if declared unfit based on the results of verification:

1. The data is not recorded in customer deposits at the bank.

2. Depositors of beneficiaries improperly.

3. The depositor is a party which caused the bank becomes unhealthy.

Act No. 24 of 2004 concerning the Deposit Insurance Agency (LPS) in Section 8 requires all banks that do business in the region of the Republic of Indonesia became a member of the Deposit Insurance Agency (LPS). So until now treatment between the Bank Conventional and Islamic Banking is still the same in addition to the specificity of Islamic Banking LPS contained in Regulation 2 of 2010 Section 44.

Article 22 subsection (1) letter a of Act No. 24 of 2004 on LPS confirmed that Bank settlement Failing that no systemic impact made by a rescue or did not do rescue of Bank Failure meant. Furthermore, according to Article 24 subsection (1) of Act No. 24 of 2004 on LPS that LPS sets out to rescue Failed Banks that do not have a systemic impact if it met the following requirements ${ }^{12}$

1. Estimated cost of the rescue is significantly lower than the

11 Mamuja, Juanda. Lembaga Penjamin Simpanan Dalam Rangka Perlindungan Hukum Bagi Nasabah Perbankan Di Indonesia. Lex Privatum, Vol.III/No. 1/Jan-Mar, 2015.

12 Napitulu Diana Ria Winati, Lembaga Penjamin Simpanan di Indonesia, Jakarta : PT Bumi Inti tama Sejahtera, 2010. 
estimated cost of the bank rescue is not done;

2. After being rescued, the bank still shows good business prospects;

3. There is a statement from the RUPS bank at least the willingness to:
a. Submit RUPS right and authority to LPS;
b. LPS handed to the bank management; and
c. Not demanding LPS or LPS designated party when the rescue process is not successful, all parties appointed LPS or LPS perform their duties in accordance with legislation

4. Banks submit to LPS documents concerning:
a. Use of the financing facility from Bank Indonesia;
b. Debitor Customer financial funds;
c. structures are at the capital and shareholding structure of 3 (three) years; and
d. Other information relating to the assets, liabilities, including bank capital needed by LPS.

After the AGM transferred its rights and authority, LPS can perform the following actions ${ }^{13}$

i. Control, manage, and perform acts of ownership of the assets belonging to or into the rights of the bank and/or liabilities of the bank;

ii. Sell or transfer assets of the bank without the consent of the debtor and/or liabilities of the bank

13 Napitulu Diana Ria Winati, Lembaga Penjamin Simpanan di Indonesia, Jakarta, PT Bumi Inti tama Sejahtera, 2010. without the consent of the lender client (purchase and assumption).

iii. Divert management of the bank to the other party;

iv. Merge or consolidate with another bank;

v. To transfer the ownership of the bank; and

vi. Reviewing cancel, terminate, and/or change the bank binding contract with a third party bank, which, according to LPS detrimental to the bank.

If all the above conditions are met, then the Deposit Insurance Agency with all of its Authority will strive to rescue the bank. But otherwise, if not met, then the Deposit Insurance Agency will propose to LPP to revoke the operating license of the bank for the next be liquidated. So it is clear that the bank rescue measures failed in the form of capital injections or Temporary Equity (PMS) is not the only action that can be performed rescue the Deposit Insurance Agency. It is understandable that many rescue action given the Deposit Insurance Corporation Act for the Deposit Insurance Agency is a last resort in order to rescue a failing bank.

Handling mechanism failed bank with systemic impact in accordance with Article 22 Subsection (1) letter b Act No. 24 of 2004 concerning the Deposit Insurance Agency stated that tackling systemic impact Failed Bank carried by a rescue involving existing shareholders or without involving the existing shareholders.

Failed Bank's handling systemic impact done by involving the existing shareholders (open bank assistance) can only be done if: 
1. Failed Bank shareholders have put up capital of at least $20 \%$ of the estimated cost of handling;

2. There is a statement from the RUPS bank at least the willingness to:

(a) Give to the Deposit Insurance Agency rights and privileges in the RUPS; (b) Submit to the Deposit Insurance Agency the management of the bank and, (c) Not require the Deposit Insurance Corporation or any other party which appointed the Deposit Insurance Agency in terms of the handling process is not successful, all the Deposit Insurance Agency or assigns the Deposit Insurance Agency carry out their duties in accordance with the legislation;

3. Banks submit to the Deposit Insurance Agency, documents concerning:

(a) Use of funding facilities from Bank Indonesia; (b) the debtor's financial data; (c) The capital structure and shareholding structure of the last 3 years and (d) other information relating to the assets, liabilities, and capital the banks needed the Deposit Insurance Agency

The Deposit Insurance Agency is responsible for the shortage of Bank Failure handling fees after the systemic impact of existing shareholders to raise more capital to at least $20 \%$ of the estimated cost of handling. Going forward, Failed Bank handling charges incurred by the
Deposit into equity while the Deposit Insurance Agency at the bank.

The Deposit Insurance Agency must sell all the shares of the bank in an open and transparent handling a maximum of 3 years and can be extended as much as 2 times with each extension for 1 year to obtain the optimal return. However, if within that period an optimum rate of return can not be realized, the Deposit Insurance Agency to sell the bank's shares in the next period of 1 year.

\section{Legal Protection for Customer Deposits at Syariah Bank with Mudharabah Contract}

Banking institutions function as an intermediary for the parties who have excess funds with the parties who need funding consequences on the emergence of intensive interaction between banks as businesses and customers Banks. Customestrs storage service user need not worry about the loss of their deposits islamic banks despite using mudharabah with the existing regulations of their deposits guaranteed repayment by the government through the deposit insurance institution, as contained in Act No. 4 of 2004 concerning the Deposit Insurance Agency, the Deposit Insurance Agency (LPS). Article 37B Law of the Republic of Indonesia No. 10 of 1998 on the amendment of Act No. 7 of 1992 concerning Banking Section 37B of the Banking Act expressly pour that:

In government regulation in lieu of law (perpu) 3 Years later passed into Act No. 7 of 2009 Article 11 stated value Deposits guaranteed for each customer in one bank most $100,000,000.00$ (one hundred million 
rupiah). Deposits guaranteed value can be changed if it met one or more of the following criteria:

a. withdrawals of banking funds in large numbers simultaneously;

b. inflation is significant in a few years;

b. the number of customers that is guaranteed throughout the savings to less than $90 \%$ (ninety percent) of the entire bank depositors; or

c. crisis occurs threats that may result in the decline of public confidence in the banking and endanger the stability of the financial system.

Changes Saves the scale of value that is guaranteed as referred to in Article 11 of Act No. 7 of 2009 set by Government Regulation and further reported to the House of Representatives.

Based on Government Regulation 66 of 2008 on the amount of the Guaranteed Savings LPS which sets the value of deposits guaranteed for each customer in one bank is at most Rp 2.000.000.000, - (two billion rupiah).

The Deposit Insurance Agency to make payments to the insurance claims depositors of banks that license has been revoked far as they meet the requirements stipulated by the Law on Insurance Agency
1. Recorded in the books of the bank.

2. The deposit interest rate does not exceed the interest rate guarantee.

3. Do not perform actions that harm the bank.

These three criteria are eligible to pay the aforesaid known as 3T. But for the interest rate on deposits do not exceed the interest rate guarantee does not apply to Islamic banks. LPS in Regulation 2 of 2010 Section 44 is stated that the interest rate is considered reasonable set LPS does not apply in determining the status of the deposit guarantee to deposits based on Islamic principles.

\section{CONCLUSION}

Legal protection in the Islamic banking depositors are protected by rules that are already fairly well from the Financial Services Authority and the Institute of deposit insurance, even the rule better than protection implied to customers of conventional banks. LPS in Regulation 2 of 2010 Article 44 stated that the interest rate is considered reasonable set LPS does not apply in determining the status of the deposit guarantee to deposits based on Islamic principles because Islamic Bank using revshare principle in operation. 


\section{BIBLIOGRAPHY}

\section{Books :}

Arifin, Zainul. Dasar-Dasar Manajemen Bank Syariah. Jakarta: Alvabet, 2005, p. 102

Arief R. Permana, S.H., M.H.1 dan Anton Purba, S.H., LL.M, Sekilas Ulasan UU Perbankan Syariah, BULETIN Hukum Perbankan Dan Kebanksentralan 1. Volume 6, No. 2, Agustus 2008

David Y. Wonok, Perlindungan Hukum Atas Hak-Hak Nasabah Sebagai Konsumen Pengguna Jasa Bank Terhadap Risiko Yang Timbul Dalam Penyimpangan Dana, Vol.I/No.2/April-June/2013 Special Edition. P. 5

Indra atmaja Agung B.G.B, Lembaga Penjamin Simpanan: Manfaatnya Bagi Nasabah dan Bank, Jakarta, Magister Hukum Universitas Indonesia, 2001.

Kuncoro, Mudrajad. Manajemen Perbankan: Teori dan Aplikasi.Yogyakarta: BPFE, 2002, p. 21

Mamuja, Juanda Lembaga Penjamin Simpanan Dalam Rangka Perlindungan Hukum Bagi Nasabah Perbankan DiIndonesia. Lex Privatum, Vol.III/No. 1/Jan-Mar, 2015.

Napitulu Diana Ria Winati, Lembaga Penjamin Simpanan di Indonesia, Jakarta, PT Bumi Inti tama Sejahtera, 2010.

Islamic Banking Statistics November 2018

Zamir Iqbal Abbas Mirakhor, Pengantar Keuangan Islam Teori dan Praktek, Jakarta: Kencana Prenada Media Group, 2008, p.131

Law of the Republic of Indonesia No. 21 of 2008 concerning Sharia Banking https://republika.co.id/berita/ekonomi/syariah-ekonomi/19/02/07/pmjysr370-pengamatperforma-perbankan-syariah-2018-semakin-kuat 